\title{
Nutrients Reclamation using Modified Membrane to Provide Added Value to the Kenaf Retted Wastewater
}

\author{
Nabilah Huda A. H., Ramlah M. T., Aida Isma M. I., Siti Aisyah G. and Sharifah A.
}

\begin{abstract}
Kenaf retted wastewater (KRW) currently contributed to water pollution problem through retting process due to increasing in demand of fiber among fibers industries. Directly discharge of nutrient-rich retting water into water body can cause eutrophication and initiated a rapid algal bloom. The aim of this study is to provide the added-value for KRW by reclamation of nutrients using modified membrane. The experiment was carried out in a filtration system using modified membrane, $\mathrm{PVP}_{1.5}$ (14.8 wt. \% Polysulfone (PSF)/ 83.7 wt. $\%$ N-Dimethylacetamide (DMAC)/ 1.5 wt. \% Polyvinyl-pyrrolidone (PVP)) as medium of filtration. It is observed that the modified membrane efficiently reclaiming more than $90 \%$ of total nitrogen (TN), nearly to $90 \%$ of total phosphorus (TP) and above $85 \%$ potassium $(\mathrm{K})$ from KRW and it successfully produced the effluent that meet the effluent standard which can be disposed into the nature at a safe level. Therefore, it is found that reclamation of nutrients from KRW using this modified membrane is one of the profitability techniques for Malaysia kenaf industries because of nutrients from 10 thousand hectares of land per season of kenaf planting is estimated able to be reclaimed as much as 126 thousand $\mathrm{kg} / \mathrm{L} \mathrm{TN}, 68$ thousand $\mathrm{kg} / \mathrm{L}$ TP and nearly 2 million $\mathrm{kg} / \mathrm{L} \mathrm{K}$. From this study, KRW has the potential to be converted into a useful product with added value and provide the added value for KRW.
\end{abstract}

Index Terms - Kenaf, membrane, nutrient reclamation, retted wastewater.

\section{INTRODUCTION}

Kenaf planting has been increased around the world due to its high biomass yield and the raised fiber content [1]. As reported by the Utusan Malaysia [2], total of 10 hectares of land in Malaysia is used for the cultivation of kenaf per season. Kenaf (Hibiscus cannabinus L.) has been identified as a new commodity crop also known as 'New Sources of Growth in Malaysia'. However, the rapid development of kenaf industry has caused environmental problem through their retting process due to it takes about one to two weeks to be completed [3]. This process is the main challenge faced during the processing of bast kenaf plants.

Water retting is a process where the fiber plant immersed in stagnant or slowly flowing water such as river and pond in order to loosen up the fiber. A quality of fiber is largely determined by the retting condition and duration [4]. This age-old practice is highly suit the economy of the third world countries and usually chosen by farmer due to the input costs are extremely low and easy to handle [5]. Moreover, this

Faculty of Civil Engineering, Universiti Teknologi MARA, 40450 Shah Alam, Selangor, Malaysia. method is believed by researchers that produce high quality of long fiber and high price in international market [6], [7].

Due to the increase in demand of fiber among fibers industries, kenaf retted wastewater (KRW) currently contributed to water pollution problem through their processing stage namely retting process. According to Dam \& Bos [8], they state that, water retting process of natural fiber takes a long time (15-18 days) for debarking. Long duration is required in traditional retting to obtain better quality fiber, but excess worse resulting water condition [9]. Directly discharge of nutrient-rich retting water into water body can cause eutrophication and initiated a rapid algal bloom due to the excess of nutrients. Then, when this sudden growth and abrupt death of these organisms consequent decomposition process resulted in deoxygenation of the aquatic ecosystem and suffocates the living species [10].

TABLE I

CHARACTERISTIC OF RETTED WASTEWATER

\begin{tabular}{|c|c|c|c|c|c|}
\hline \multirow{2}{*}{ Parameter } & \multicolumn{5}{|c|}{ Published Data } \\
\hline & [11] & [12] & [13] & [14] & [7] \\
\hline $\mathrm{pH}$ & 7.5 & 5.7 & NT & 4 & $3.5-5.5$ \\
\hline Free $\mathrm{CO}_{2}$ & 4.9 & NT & NT & NT & NT \\
\hline Color & NT & NT & NT & 2390 & $1000-1200$ \\
\hline DO & 1.4 & 0.04 & NT & NT & NT \\
\hline BOD & 2377 & 14.73 & NT & 20 & $70-230$ \\
\hline COD & 840 & 1633 & NT & 2300 & $2000-2500$ \\
\hline SS & NT & 186.6 & NT & 550 & $200-500$ \\
\hline $\mathrm{TS}$ & NT & NT & NT & 2400 & $2200-2400$ \\
\hline Turbidity & NT & 28 & NT & 500 & $180-280$ \\
\hline $\mathrm{N}_{2}$ & NT & NT & 47 & 13.5 & NT \\
\hline $\mathrm{NH}_{3}-\mathrm{N}$ & 0.8 & 26 & NT & NT & $4-20$ \\
\hline $\mathrm{NO}_{3}-\mathrm{N}$ & 0.1 & NT & NT & NT & $0.15-0.35$ \\
\hline $\mathrm{P}$ & NT & NT & 4.4 & 7.7 & $30-40$ \\
\hline $\mathrm{K}$ & NT & NT & 871 & NT & NT \\
\hline
\end{tabular}

This activity was seriously affected the nearby water sources as well as odorous problems. Wastewater generated from the retting process produces greenish color, high in suspended solids, high biochemical oxygen demand (BOD) load, reduction of dissolved oxygen (DO), an increase in the free carbon dioxide level of water [5], [14]. In addition, the degradation process produce unpleasant odor. The condition of KRW is unacceptable from an aesthetic value and it also still unreasonably discarded [14].

Table I shows the characteristic of retting water obtained from previous study. They found that, the concentration of organic pollutant is high and some of them are above the effluent standard. Chemical oxygen demand (COD) found to be the highest concentration among others parameter. According 
to Zawani et al. [7] the main contributor of COD concentration due to existing organic matter in KRW allows the reaction between chemicals and organic compounds to occur. As the organic fiber was now expanding their demand this process is of course never ended although several controversies were recorded.

At present, wastewater generated from retting process usually released and disposed without improperly treatment [14], [15]. Consequently, not only human are affected, in fact, animal and the environment as well. Although, organic degradation and accumulation of microbial biomass are not considered toxic, but the process can causes depletion of oxygen and foul smell emissions in the retting area [8], [16]. Thus it will create environmental problems such as eutrophication and threaten the aquatic life which is living in the water retting area [16].

This link to study made by Mondal \& Kaviraj [11], they stated that retted wastewater was correlated significantly as causes to mortality of aquatic life such as $H$. molirix and $L$. rohita. This is due to a deficit of DO and subsequent cause respiratory deficiency of aquatic life appears to be the principal causes of mortality.

TABLE II

APPLICATION OF VALUABLE PARAMETER

\begin{tabular}{|c|c|c|c|}
\hline Parameter & Valuable & Waste & Application \\
\hline $\mathrm{pH}$ & & $\sqrt{ }$ & \\
\hline Free $\mathrm{CO}_{2}$ & & $\sqrt{ }$ & \\
\hline Color & & $\sqrt{ }$ & \\
\hline DO & $\sqrt{ }$ & & $\begin{array}{l}\text {-Essential elements for aquatic life, } \\
\text { importance measurement for health of } \\
\text { water body }\end{array}$ \\
\hline BOD & & $\sqrt{ }$ & \\
\hline COD & & $\sqrt{ }$ & \\
\hline SS & & $\sqrt{ }$ & \\
\hline TS & & $\sqrt{ }$ & \\
\hline Turbidity & & $\sqrt{ }$ & \\
\hline $\mathrm{N}_{2}$ & $\sqrt{ }$ & & $\begin{array}{l}\text {-Fertilizer, freeze food, reduce VOCs } \\
\text { emissions, scavenger, solvent, freeze } \\
\text { and preserve live tissue samples, burn } \\
\text { warts and small benign skin tumors }\end{array}$ \\
\hline $\mathrm{P}$ & $\sqrt{ }$ & & $\begin{array}{l}\text {-Fertilizer, steel production, military } \\
\text { applications, water softening }\end{array}$ \\
\hline K & $\sqrt{ }$ & & $\begin{array}{l}\text {-Fertilizer, liquid soap, } \\
\text { pharmaceuticals, saline drips }\end{array}$ \\
\hline
\end{tabular}

Even though most of the characteristic of retted wastewater can be consider as waste such as BOD, COD, suspended solid (SS), and total solid (TS) which is should be removed during wastewater treatment, but there are few valuable asset that are essential or have been used in many application especially nutrients element as show in Table II. Islam \& Rahman [13] stated that retted wastewater contained high of nutrients concentration and was identified as composition in fertilizers.

Therefore, KRW not only should be treated or removed the organic contaminants, but it also should undergo the nutrients reclamation, so that beneficial element can be reuse back. Moreover, wastewater from production processes of natural fibers was recognized to caused water pollution, yet, contaminants contain in this wastewater is only consists of biodegradable compounds. With this, Dam \& Bos [8] expect that the wastewater treatment for natural fiber production therefore would be technically easier and cheaper. Furthermore, if the application of treated wastewater into kenaf plant may contribute to mitigate the scarcity of water resources and to reduce the fertilizers needs as well as reuse beneficial components in wastewater, therefore, the global positive environmental outcomes can be produced. Therefore, this study to provide the added-value for $\mathrm{KRW}$ by reclamation of nutrients using modified membrane.

\section{EXPERIMENTAL}

\section{A. Synthetic KRW Preparation}

Kenaf retted wastewater (KRW) was prepared in pilot scale. The fresh green kenaf plants (V36) harvested between 4-5 months were supplied by the National Kenaf and Tobacco Board (NKTB) located in Kelantan, Malaysia. Meanwhile, river water from kenaf planting area was used as available water source.

Kenaf bast fibers were retted in water for 14 days with the minimum ratio of fiber to water $1 \mathrm{~kg}$ : $2 \mathrm{~L}$. This ratio is chosen in term of reduce of water consumption and to gain the maximum concentration of KRW and being use by farmer at rural area [17]. On day 14, the fibers were removed from the container and the wastewater was kept in a container prior to being used for nutrients reclamation using membrane.

\section{B. Operation of Pilot Scale of Nutrients Reclamation using Modified Membrane}

The experiment was carried out in a filtration system. The filtration system was operated starting from feed tank. The modified membrane, $\mathrm{PVP}_{1.5}$ was filtrated with ultrapure water (UPW) at 5 bar for half an hour to get steady permeate flow. Modified membrane, $\mathrm{PVP}_{1.5}$ made of 14.8 wt. \% Polysulfone (PSF)/ 83.7 wt. \% N, N-Dimethylacetamide (DMAC)/ 1.5 wt. $\%$ Polyvinyl-pyrrolidone (PVP) and having $43 \%$ rejection of salt solution and $339.53 \mathrm{~L} / \mathrm{m}^{2} . \mathrm{h}$ water flux was used as filtration medium. After pure water filtration, the flat membrane cell and the feed tank were emptied and refilled rapidly with KRW. Then, with the constant pressure of 5 bar supplied by pumping system, KRW sample was allowed to pass through the membrane. The feed, permeated, rententated of KRW was taken to determine its concentration before and after the filtration process by using HACH method. Each of samples was tested for three runs. Later, the percentage of flux and rejection of KRW for feed, rententated and permeated was calculated on (1) and (2) [18],

$$
J_{w}=\frac{V}{A / \Delta t}
$$

where, $J_{w}\left(\mathrm{~L} / \mathrm{m}^{2} . \mathrm{h}\right)$ is water flux, $V(\mathrm{~L})$ is the volume of water permeated, $A\left(\mathrm{~m}^{2}\right)$ is the effective membrane area, and $\Delta t(\mathrm{~h})$ is the operation time.

$$
\boldsymbol{R}_{r}=\left(1-\frac{C_{b}}{C_{a}}\right) \times 100
$$

where, $R_{r}(\%)$ is nutrients reclamation, $C_{a}(\mathrm{mg} / \mathrm{l})$ is the concentration of nutrient after the membrane separation and $C_{b}$ 
is the concentration of nutrient before the membrane separation.

\section{A. Analytical Method}

For laboratory analysis, BOD was determined by measuring oxygen demand for 5 days using BOD meter. $\mathrm{pH}$ and DO were determined using $\mathrm{pH}$ meter (HACH Sensions3, USA) and DO meter, respectively. Reactor digestion method which is approved by the USEPA was used for determination of COD. Suspended Solid (SS) was determined using Photometric method adapted from Sewage and Industrial Wastes, 31, 1159 (1969). By using HACH spectrophotometer, total nitrogen (TN), total phosphorus (TP) and potassium (K) were analyzed using Persulfate digestion method, Phosver3 (ascorbic acid) method, and Tetraphenylborate method, respectively. The procedures were based on the HACH standard [19]. All the units of concentration were in $\mathrm{mg} / \mathrm{L}$ except for $\mathrm{pH}$. The wastewater samples were characterized immediately within a day after collection and were replicated for three times

\section{Results And Discussions}

\section{A. Performance of Nutrients Reclamation}

Table III listed the results of KRW. The wastewater results were compared with the Malaysian Effluent Standard that regulated by the Department of Environment (DOE) Malaysia [20]. It is important to identify either the wastewater has allowed to be released into water stream or required further treatment.

TABLE III

ANALYZES MEAN RESULTS OF KENAF RETTED WASTEWATER FROM RATIO KENAF TO WATER 1:2

\begin{tabular}{lcccc}
\hline \hline Parameter & $\begin{array}{c}\text { Permissible Limits of } \\
\text { Malaysian Effluent } \\
\text { Standard }\end{array}$ & $\begin{array}{c}\text { KRW } \\
\text { (Raw) }\end{array}$ & $\begin{array}{c}\text { Filtrated } \\
\text { Water }\end{array}$ & $\begin{array}{c}\text { Reclaimed } \\
\text { Water }\end{array}$ \\
\hline pH & $5.5-9.0$ & 4.81 & 5.90 & NA \\
DO & $3.00-5.00$ & 3.90 & 7.21 & NA \\
BOD 5 & 50 & 456.00 & 43.68 & NA \\
COD & 100 & 1970.00 & 96.40 & NA \\
SS & 100 & 400.00 & 37.30 & NA \\
TN & NA & 25.00 & 1.70 & 23.30 \\
TP & NA & 14.00 & 1.44 & 12.56 \\
K & NA & 370.00 & 50.20 & 319.80 \\
\hline Note: NA = Not Available & & &
\end{tabular}

From the results obtained, it is found that KRW containing wastewater pollutant concentrations which has high in physico-chemical parameters. Long duration is required in traditional retting to obtain better quality fiber, but excess worse resulting water condition [9]. KRW need to go through for further treatment since most of the parameters did not comply with the Malaysian effluent standard which regulated by DOE. Nutrients rich in retted wastewater that enter into water course can cause eutrophication and initiated a rapid algal bloom due to the overabundance of nutrients. Then, when this sudden growth and abrupt death of these organisms, decomposition process resulted in deoxygenation of the aquatic ecosystem and suffocated the living species [10].

Moreover, nutrient parameters can be considered as high and can be a good potential alternative source of nutrients and is suitable for kenaf growth. This coincide with Mathre [10] when the retted water are treated before release to the environment, they do not cause such an effect or may even prove useful if utilized as an organically enrich irrigation water for crop.

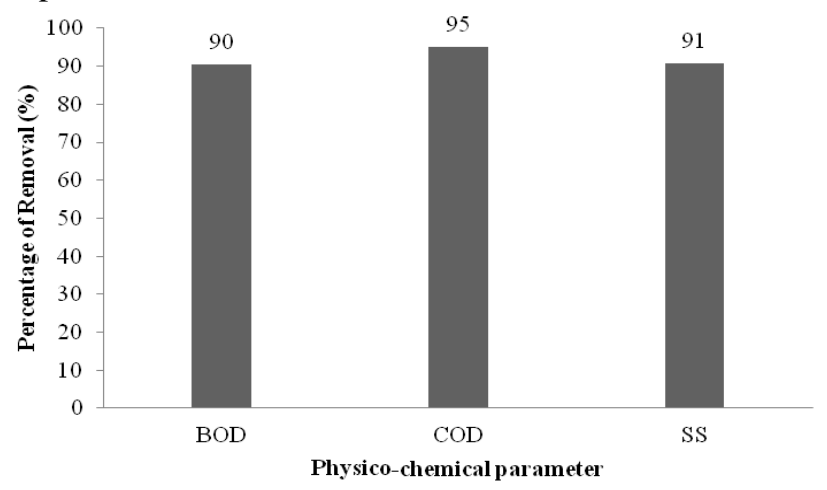

Fig. 1. Percentage Removal of Physico-chemical Parameter from KRW using $\mathrm{PVP}_{1.5}$ Membrane.

The treatment of KRW using modified membrane, $\mathrm{PVP}_{1.5}$ is working efficiently in filtration and reclaims the nutrients from $\mathrm{KRW}$, and it is providing satisfactory removal of COD, $\mathrm{BOD}_{5}$, $\mathrm{SS}$ and all forms of nutrients which are TN, TP and $\mathrm{K}$ as shown in Table III. In addition, value of $\mathrm{pH}$ and $\mathrm{DO}$ have also improved. Through the filtration process, the reduction of $\mathrm{COD}, \mathrm{BOD}_{5}$ and $\mathrm{SS}$ concentration were achieved up to $90 \%$ as illustrated in Fig. I. The KRW was improved for $\mathrm{BOD}_{5}, \mathrm{COD}$ and SS parameters in reducing the concentration from 456 $\mathrm{mg} / \mathrm{L}$ to $43.68 \mathrm{mg} / \mathrm{L}, 1970 \mathrm{mg} / \mathrm{L}$ to $96.40 \mathrm{mg} / \mathrm{L}$ and 400 $\mathrm{mg} / \mathrm{L}$ to $37.3 \mathrm{mg} / \mathrm{L}$, respectively. In addition, all these parameter value is in the permissible limit set by Malaysian DOE even though $\mathrm{BOD}_{5}$ and COD comply with the effluent standard, but in the concentration difference value between filtered water and effluent standard is small about $6.32 \mathrm{mg} / \mathrm{L}$ and $3.6 \mathrm{mg} / \mathrm{L}$ respectively.

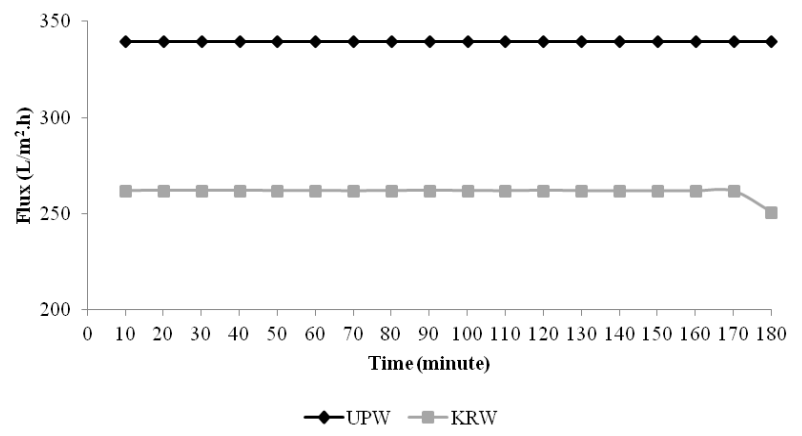

Fig. 2. Comparison of Anti-pressure Stability Test of $\mathrm{PVP}_{1.5}$ Membrane versus Time using UPW and KRW.

Moreover, $\mathrm{PVP}_{1.5}$ membrane is able to increase the $\mathrm{pH}$ value to near the neutral level and followed the standard by DOE Malaysia. The $\mathrm{PVP}_{1.5}$ membrane was resistant to $\mathrm{pH}$ of wastewater due to it made from PSF polymer that is resistant to the $\mathrm{pH} 2-13$ [21]. This result is supported with the anti-stability tests of $\mathrm{PVP}_{1.5}$ membrane through this wastewater in 180 minutes. The comparison results of anti-stability test for $\mathrm{PVP}_{1.5}$ in 180 minutes between UPW and KRW were demonstrated 
using lines graph in Fig. 2. The water flux of the membrane using KRW is below than flux of UPW, which is $261.8 \mathrm{~L} / \mathrm{m} 2 . \mathrm{h}$ and it started to decrease slowly until $254.6 \mathrm{~L} / \mathrm{m} 2 . \mathrm{h}$, from minute of 170 to the minute of 180 . It can be seen that, the reduction of water flux between UPW and KRW is only 26.15 $\%$. This can be observed that, $\mathrm{PVP}_{1.5}$ membrane had remained almost constant in water flux even in terms high concentrated of wastewater. This shows that the modified membrane absolutely resistant to $\mathrm{pH}$ even up to 180 minutes where the stability water flux was shown. The decrease of water flux from minute of 170 to minute of 180 is due to high of contaminants and suspended solid in KRW.

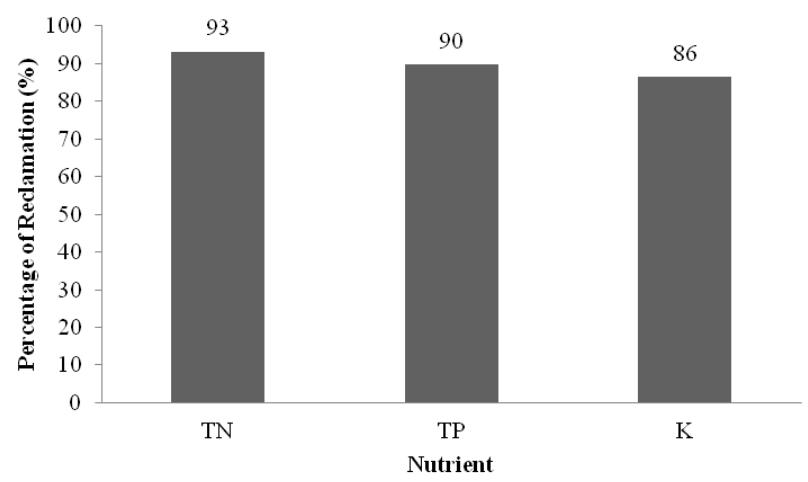

Fig. 3. Reclamation Percentage of Nutrients from KRW using $\mathrm{PVP}_{1.5}$ Membrane.

Moreover, the result listed in Table III show that the modified membrane, $\mathrm{PVP}_{1.5}$ was effective and ideal for reclamation of nutrients from KRW since it is successful to reduce the TN, TP and $\mathrm{K}$ as low as $1.7 \mathrm{mg} / \mathrm{L}, 1.44 \mathrm{mg} / \mathrm{L}$ and $50.2 \mathrm{mg} / \mathrm{L}$, respectively. Based on Fig. 3, the bar chart shows that TN exhibited the highest reclamation rate, which is $93 \%$ compared to the others nutrients, TP and $\mathrm{K}$ which is above 85 $\%$. This result was in line with Innocenti et al. [22] in their study in removal of nutrients and metal using ultrafiltration technology which found that this membrane technology are able to remove COD, ammonia-nitrogen and phosphorus 93.56 $\%, 97.80 \%$, and $75 \%$. It can thus be concluded that, this modified membrane is efficient in the reclamation of TN, TP and $\mathrm{K}$ from KRW.

\section{B. Profitability of Nutrients Reclamation in Malaysian} Kenaf Plantation

Table IV shows the nutrients reclaimed from a hectare kenaf plantation only produce $12.58 \mathrm{~kg} / \mathrm{L} / \mathrm{ha}$ of TN, $6.77 \mathrm{~kg} / \mathrm{L} / \mathrm{ha}$ of TP and $172.64 \mathrm{~kg} / \mathrm{L} / \mathrm{ha}$ of $\mathrm{K}$ which considered as low compared to the study made by Hossain et al. [1] for maximum growth and photosynthesis rate, kenaf plant need the nutrient rate of $200 \mathrm{~kg} / \mathrm{ha}$ of $\mathrm{N}, 100 \mathrm{~kg} / \mathrm{ha} \mathrm{P}$ and $100 \mathrm{~kg} / \mathrm{ha}$ of K. Although amount of nutrient reclamation from KRW is seen only little from the fertilizer used for kenaf plantation and just potassium is able to meet the basic needs of kenaf, but from the point of a whole Malaysia production view, it is found that this method was able to reclaim its original nutrients from the water kenaf waste in large quantities.
TABLE IV

PROFITABILITY OF NUTRIENTS RECLAMATION IN MALAYSIAN KENAF PLANTATION

\begin{tabular}{|c|c|c|c|c|}
\hline \multirow{2}{*}{ Kenaf } & \multirow{2}{*}{$\begin{array}{l}\text { Water } \\
\text { used }\end{array}$} & \multicolumn{3}{|c|}{ Nutrients Reclamation } \\
\hline & & TN & TP & $\mathrm{K}$ \\
\hline $1 \mathrm{~kg}$ & $2 \mathrm{~L}$ & $\begin{array}{l}23.30 \\
\mathrm{mg} / \mathrm{L}\end{array}$ & $\begin{array}{l}12.55 \\
\mathrm{mg} / \mathrm{L}\end{array}$ & $\begin{array}{c}319.70 \\
\mathrm{mg} / \mathrm{L}\end{array}$ \\
\hline $\begin{array}{l}60 \mathrm{tan} / \mathrm{ha} / \mathrm{season} \sim \\
54,000 \mathrm{~kg}\end{array}$ & $108 \mathrm{~K} \mathrm{~L}$ & $\begin{array}{c}12.58 \\
\mathrm{~kg} / \mathrm{L} / \mathrm{ha}\end{array}$ & $\begin{array}{c}6.77 \\
\mathrm{~kg} / \mathrm{L} / \mathrm{ha}\end{array}$ & $\begin{array}{c}172.64 \\
\mathrm{~kg} / \mathrm{L} / \mathrm{ha}\end{array}$ \\
\hline $\begin{array}{l}\text { Fertilizer/ Nutrients } \\
\text { rate [1] }\end{array}$ & sumption & $200 \mathrm{~kg} / \mathrm{ha}$ & $100 \mathrm{~kg} / \mathrm{ha}$ & $100 \mathrm{~kg} / \mathrm{ha}$ \\
\hline
\end{tabular}

Where Malaysia was produce as much as 60 tons of kenaf stems from a hectare of land in a season. According to report Utusan Malaysia by Hamid [2], total of 10 hectares of land in Malaysia is used for the cultivation of kenaf per season, and it is estimated that 600 thousand tons kenaf stalks produced and if all these plants go through kenaf retting process, so it will produce as much as 1 billion of KRW when water retting process using the ratio of kenaf to water is 1: 2 . Therefore, nutrients from 10 thousand hectares of land per season of kenaf planting is estimated to be reclaimed is as much as 126 thousand $\mathrm{kg} / \mathrm{L} \mathrm{TN}, 68$ thousand $\mathrm{kg} / \mathrm{L}$ TP and nearly 2 million $\mathrm{kg} / \mathrm{L} \mathrm{K}$.

Therefore, it is found that reclamation of nutrients from KRW using modified membrane is one of the profitability techniques for Malaysia kenaf industries. Reclaimed nutrients which are produced can be reused as alternative liquid organic fertilizer for kenaf plantation. Moreover, it can be beneficial to the farmers in reduce cost of buying the fertilizer owing to the high cost of synthetic fertilizers, besides, the problem of environmental pollution and disposal of difficulty can be solved. It is just like killing two birds with one stone, where filtered water can be discharged safely into water course; meanwhile retentated water can be used for plant as liquid fertilizer.

\section{CONCLUSION}

The modified membrane consist of 14.8 wt. \% PSF/ 83.7 wt. $\%$ DMAC/ 1.5 wt. \% PVP, was effective in reclamation of nutrients from KRW and is an ideal membrane since it successful to reduce the concentration of TN, TP and $\mathrm{K}$ as low as $1.7 \mathrm{mg} / \mathrm{L}, 1.44 \mathrm{mg} / \mathrm{L}$ and $50.2 \mathrm{mg} / \mathrm{L}$, respectively. $\mathrm{PVP}_{1.5}$ membrane is able to reclaim $93.20 \%$ of TN, $89.71 \%$ of TP and $86.61 \%$ of $\mathrm{K}$ from KRW. Therefore, it is found that reclamation of nutrients from KRW using this modified membrane is one of the profitability techniques for Malaysia kenaf industries because of nutrients from 10 thousand hectares of land per season of kenaf planting is estimated able to be reclaimed as much as 126 thousand $\mathrm{kg} / \mathrm{L} \mathrm{TN}, 68$ thousand $\mathrm{kg} / \mathrm{L}$ $\mathrm{TP}$ and nearly 2 million $\mathrm{kg} / \mathrm{L} \mathrm{K}$. The modified membrane also efficiently produced the effluent meet the effluent standard which can be disposed at a safe level into the nature. After membrane treatment on KRW, amount of wastewater was reduced by half. Besides produced the concentrated wastewater rich in nutrients and can be reused as alternative liquid organic fertilizer which is suitable for plant growth. This can be beneficial to the human and the environment. From this study, $\mathrm{KRW}$ has the potential to be converted into a useful product 
and provide the added value for KRW. Then can solve the problem of environmental pollution and difficulty of disposal.

\section{ACKNOWLEDGMENT}

The authors would like to express greatest appreciation to the National Kenaf and Tobacco Board and the Faculty of Civil Engineering of Universiti Teknologi MARA for providing necessary facilities, also to the SEGi University for financial support in this research. Not to forget, Mr. Hazri Othman due to his assistance during laboratory work.

\section{REFERENCES}

[1] M. D. Hossain, M. M. Hanafi, J. Talib, and H. Jol, "Effects of nitrogen, phosphorus and potassium levels on kenaf (Hibiscus cannabinus L.) growth and photosynthesis under nutrient solution," J. Agric. Sci., vol. 2, no. 2, pp. 49-57, 2010. http://dx.doi.org/10.5539/jas.v2n2p49

[2] N. Hamid, "Commercialize kenaf plants," Utusan Malaysia, Kuala Lumpur, Malaysia, 2012.

N. Hamid, "Komersialkan tanaman kenaf," Utusan Malaysia, Kuala Lumpur, Malaysia, 2012.

[3] S. Mahmudin, Z. M. A. Ainun, J. Latifah, M. Shahwahid, M. T. Paridah, A. Sharmiza, Singaram, M. Y. Mohd Nor, and H. Jalaluddin, Kenaf - A Potential Fibre for Pulp and Paper Manufacture. Kuala Lumpur, Malaysia: Zull Creative, 2012.

[4] M. T. Paridah and A. Khalina, "Effects of soda retting on the tensile strength of kenaf (Hibiscus cannabnius L.) bast fibres.," Selangor, Malaysia, 2009.

[5] A. Banik, M. Sen, and S. P. Sen, "Methane emission from jute-retting tanks," Ecol. Eng., vol. 2, pp. 73-79, 1993. http://dx.doi.org/10.1016/0925-8574(93)90028-E

[6] M. D. M. Daud, M. M. Yusoff, N. S. Nasarudin, Z. A. Hassan, N. A. L. N. Mohamed, W. C. Chee, M. N. M. Amin, and A. Othman, "Manual of Kenaf Production Technology in Malaysia," Serdang, Selangor Malaysia, 2015. M. D. M. Daud, M. M. Yusoff, N. S. Nasarudin, Z. A. Hassan, N. A. L. N. Mohamed, W. C. Chee, M. N. M. Amin, and A. Othman, "Manual Teknologi Pengeluaran Kenaf Di Malaysia," Serdang, Selangor Malaysia, 2015.

[7] Z. Zawani, L. C. Abdullah, and K. Abdan, "Characterization of kenaf fibre-retting wastewater," Int. J. Sci. Res., vol. 4, no. 6, pp. 314-317, 2015.

[8] J. E. G. Van Dam and H. L. Bos, The environmental impact of fibre crops in industrial applications. Wageningen, Netherlands: Wageningen UR, 2004.

[9] N. Reddy and Y. Yang, "Biofibers from agricultural byproducts for industrial applications.," Trends Biotechnol., vol. 23, no. 1, pp. 22-7, Jan. 2005. http://dx.doi.org/10.1016/j.tibtech.2004.11.002

[10] R. N. M. L. Mathre, Cannabis in medical practice: A legal, historical and pharmacological overview of the therapeutic use of marijuana. United States, America: McFarland, 1997.

[11] D. K. Mondal and A. Kaviraj, "Ecotoxicological effects of jute retting on the survival of two freshwater fish and two invertebrates.," Ecotoxicology, vol. 17, no. 3, pp. 207-211, Apr. 2008. http://dx.doi.org/10.1007/s10646-007-0185-6

[12] M. N. Othman, R. M. Tajuddin, Z. Ahmad, and M. F. Ali, "The quality of kenaf retting water after retting using Bacillus cereus for fiber extraction," in International Civil and Infrastructure Engineering Conference, 2013, pp. 823-836. "unpublished"

[13] M. M. Islam and M. M. Rahman, "Advances in Jute and allied fibres post-harvest processing technologies in Bangladesh : Adoption constraints, prospect and future thrust," J. Sci. Resour., vol. 1, no. September, pp. 20-30, 2013.

[14] Z. Zawani, L. Chuah-Abdullah, F.-R. Ahmadun, and K. Abdan, "Acclimatization process of microorganisms from activated sludge in kenaf-retting wastewater," Dev. Sustain. Chem. Bioprocess Technol., pp. 59-64, 2013. http://dx.doi.org/10.1007/978-1-4614-6208-8_8

[15] B. W. Winarto and J. Hartono, "Process of kenaf become fibre," Malang, Indonesia, 1995.

B. W. Winarto and J. Hartono, "Proses pengolahan kenaf menjadi serat," Malang, Indonesia, 1995.
[16] S. Banerjee and M. G. Dastidar, "Use of jute processing wastes for treatment of wastewater contaminated with dye and other organics," Bioresour. Technol., vol. 96, no. 17, pp. 1919-1928, Nov. 2005. http://dx.doi.org/10.1016/j.biortech.2005.01.039

[17] M. T. Ramlah, "Pemprosesan kenaf secara water retting/bioretting," in Malaysia International Commodity Conference and Showcase, 2013.

[18] R. Muppalla, H. H. Rana, S. Devi, and S. K. Jewrajka, "Adsorption of pH-responsive amphiphilic copolymer micelles and gel on membrane surface as an approach for antifouling coating," Appl. Surf. Sci., vol. 268, pp. 355-367, Mar. 2013. http://dx.doi.org/10.1016/j.apsusc.2012.12.098

[19] HACH, DR5000 Spectrophotometer: Procedures manual, 2nd ed. Germany: HACH Company, 2005.

[20] M. DOE, "Environmental quality (industrial effluent) regulations," in Environmental Quality Act 1974, Kuala Lumpur, Malaysia: Percetakan Nasional Malaysia Berhad, 2009.

[21] C. E. Scott, "Polysulfone," 2001. [Online]. Available: http://www.polymerprocessing.com/. [Accessed: 08-Jun-2012].

[22] L. Innocenti, D. Bolzonella, P. Pavan, and F. Cecchi, "Effect of sludge age on the performance of a membrane bioreactor: influence on nutrient and metals removal," Desalination, vol. 146, no. 1-3, pp. 467-474, Sep. 2002. http://dx.doi.org/10.1016/S0011-9164(02)00551-9

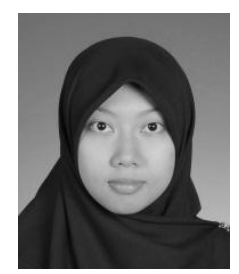

Nabilah Huda A. H. is a Master Student in Faculty of Civil Engineering in Universiti Teknologi MARA, Shah Alam, Selangor, Malaysia. The author's was born on 20 Rabi'ulawal $1408 \mathrm{H}$ (31 ${ }^{\text {st }}$ October 1988) at 'rice bowl' state of Malaysia, which is Kedah. Her primary education and secondary education are in Sungai Petani, Kedah which are in Sek. Keb. Sungai Petani and Sek. Men. Keb. Convent Father Barre. The author's continued tertiary studies at Kolej Mara Kulim, Kulim, Kedah in Matriculation level. In year 2010, the author's was graduated in Bachelor of Environmental Science at Universiti Putra Malaysia, Serdang, Selangor. Then, she is pursuing her Master by research in Civil Engineering in Universiti Teknologi MARA, Shah Alam, Selangor.

She's done her industrial training in National Hydraulic Research Institute Malaysia (NAHRIM), Seri Kembangan, Selangor and place under Water Quality Center in year 2009. After graduated, she was joined a private sector for one year as ASSISTANT ENGINEER and responsible in design and build the Sewage Treatment Plant. After that, the author's was worked as RESEARCH ASSISTANT for two years (2011-2013) in Universiti Teknologi MARA, Shah Alam, Selangor and for one year (2014-2015) in collaboration project with SEGi University, Malaysia.

She were published her paper in Proceeding of PAWEES - INWEPF Joint International Conference 2015, Universiti Putra Malaysia, Serdang, Selangor, with title "Polysulfone Membrane Tests for Nutrients Reclamation of Kenaf Retted Wastewater", Proceeding of Brunei International Conference Engineering and Technology 2014, Institut Teknologi Brunei, Bandar Seri Begawan, Brunei with paper entitle "Reclamation of Nutrient from Kenaf Retted Wastewater Using Newly Designed Ultrafiltration Membrane", and Proceeding of Malaysian Science Technology Congress 2012, Sime Darby Convention Centre, Bukit Kiara, Kuala Lumpur with paper title "A Study of Kenaf Retting Performance Using Aerated Retting Procedure for Fiber Production". Her life goals are to be versatile, knowledgeable, and also beautiful, but the most importantly make it real and stay humble 